\title{
The content of international studies
}

\section{in college: a review}

Ernst B. Haas and Allen S. Whiting, Dynamics of International Relations

Charles A. McClelland, College Teaching of International Relations

Hans J. Morgenthau, Politics Among Nations

A. F. K. Organski, World Politics

Norman J. Padelford and George A. Lincoln, The Dynamics of International Politics

James N. Rosenau (ed.), International Politics and Foreign Policy: A Reader in Research and Theory

Charles P. Schleicher, International Relations

John G. Stoessinger, The Might of Nations

KENNETH E. BOULDING

Department of Economics, The University of Michigan

The following impressions are based on six popular textbooks used in college courses in international relations: Haas and Whiting (1956), Morgenthau (1960), Organski (1958), Padelford and Lincoln (1962), Schleicher (1962), and Stoessinger (1961), together with one reader, edited by Rosenau (1961), and a research report by McClelland (1962).

The appearance within a relatively short period of these six textbooks, together with some other equally worthy books not included in this sample, seems to mark the emergence of international studies as a separate academic discipline, if not yet a major department of the social sciences. The newness of the field is perhaps indicated by the diversity of titles, and even of content, of these texts, and also by the fact that it still does not have a universally recognized name, though "International Studies," which conveniently distinguishes the field of study from "International Relations," the phenomenon studied, seems now to be leading the field, especially since the formation of a professional society called the International Studies Association-incidentally, another symptom of approaching maturity. One might describe the field, therefore, as one in late adolescence, and the texts reflect 
both the energy and the uncertainty of this period of development.

Of the texts themselves the oldest, and still the most distinguished, is Morgenthau, the first edition of which was published as early as 1948. Morgenthau is a man with an intellectual mission and a strong point of view which has been the center of considerable controversy. To judge from this third edition, however, the controversy has neither hardened his point of view nor soured his disposition; rather he seems to have learned from his critics, and modified what may have originated as a protest into a complex and broad perspective. In his earlier works, Morgenthau was noted as an exponent of the "tough" school of international theorists, protesting against a too tender-minded and moralistic approach, and stressing the importance of national interest and power as the key concepts in international relations. In this later work, however, he gives a great deal of weight to factors such as values, charisma, and the ability to attract feelings of empathy and identification, and he sees clearly that the power to injure is only a part of the complex structure of the international social system, and that the use and influence of military power cannot be understood except in a very complex setting of other social institutions and forces. His attack on militarism, for instance (p. 161), which he defines as "the conception that the power of a nation consists primarily, if not exclusively, in its military strength" puts him well towards the side of the angels, and his similar attacks on other monistic attempts at explaining international systems qualify him, at least negatively, as a systems theorist. One wonders, however, if the modification of his original position has gone so far that the whole "national interest" theory becomes almost drained of content. To say that a nation follows its national interest is rather like saying that an individual maximizes utility; unless something can be specified about the contents and formation of the values of the decisionmaker, the theory amounts to very little more than saying that nations, or persons, do what they do.

There is also a fallacy into which Morgenthau himself does not fall, at least very far, but which is often attributed to him; this is the identification of national interest with national power, and the further identification of national power with armaments and armed forces, so that a rise in the absolute level of the power to injure seems always to be in the national interest. Morgenthau sees that this is not so, but never quite faces up to the question of what does measure national interest, if power and armaments do not. Thus, while the concept of national interest starts off by looking as if it might be an objective variable, independent of the whims of men like the economists' concept of value as relative prices, it turns out in fact to be a concept riddled with subjectivity, and is certainly not to be identified with power. The national interest, indeed, is what nations are interested in, and historically they have been interested in innumerable things besides power, so that power is a very poor measure of interest.

Even though I have grave reservations about its basic theoretical framework, I must commend the Morgenthau work for its rich insights, and a constant attempt to give the student a feeling for the complex but nonrandom nature of the world social system. Every few pages one comes on something which gives intellectual pleasure, even where one may not agree; the questions that he asks and the priority which he awards to different topics give an impression of a maturing science, holding in mind simultaneously a large number of different but related processes-threats, promises, valuations, customs, challenges, responses, habits, 
laws, interwoven in an ongoing process. One would like to see more emphasis on the geographical basis of power and interaction, and I would personally like to see more attention given to the unspectacular but immensely important integrative processes of which violence and war are properly regarded as an interruption. I did not expect to like Morgenthau, knowing some of his earlier work and his reputation; I was most pleasantly surprised.

The other five texts strike me as less distinguished, though none of them is outrageous. The Padelford and Lincoln book is well-proportioned and the most up-todate. It is the only one which even begins to recognize adequately the revolutionary character of the nuclear weapon, and even though the theory is implicit rather than explicit, one feels that the authors have a theoretical backbone behind the plumpness of illustration. Lincoln teaches at West Point and, if the book is any indication of what goes on there, our future warriors may emerge almost dangerously sophisticated. The Organski book is perhaps the most ambitious, and tries to use the concept of national power as a basic variable on which to hang the whole story. The weakness of the power concept becomes apparent when he is forced to use national income as the only measure of national power that he can find. The real difficulty with the national power concept is that while the concept of purchasing power can be generalized, as it is in economics, it is doubtful whether the concept of "threatening power" (if that is what national power really means) can similarly be reduced to an abstract quantity, simply because how much power there is depends so much on what it is used for. The same theoretical problem exists in economics in the concept of purchasing power; a dollar may buy a lot of vice but little virtue, and hence means something differ- ent depending on what we buy with it. In economics, however, we can usually assume that this problem is of a second order of magnitude and can be neglected in first approximations. I suspect this is not so in politics, and hence the attempt to build a theory of international systems, or even of internal politics, on the power concept is almost certain to break down on the sheer heterogeneity of the concept. Organski's book is marred also with a large number of factual errors, especially in regard to colonialism. He has little sense of the importance of geographical space, and little appreciation of the nature of the nuclear revolution. Therefore I would reckon the book an ambitious failure, but it is at least lively, and a mature student might be challenged by it. The beginning student will get a picture of the international system that seems to me hopelessly one-sided, inadequate, and at many points inaccurate.

The Stoessinger book has an ambitious title (The Might of Nations) suggestive of Adam Smith and of an Organski-type "power" approach. Actually, most of the book is fairly bland "current history" and falls close to what I have elsewhere described as "high class journalism." Part IV is headed "Toward a Theory of International Relations," but only has a single chapter on "Image and Reality in World Politics"-which makes a very good point (that behavior depends on images which frequently do not reflect "reality"), but which makes little attempt to get at the basic problem of what constitutes reality and how we test our images in international systems. Spaghetti with one meat ball is not enough, and the student will not get much out of this volume in the way of intellectual protein.

The Schleicher book is heavy on factual and descriptive material. He manages to discuss nationalism for nearly fifty pages 
without ever mentioning the role of the armed forces, and there is again very little sense of the drastic change imposed by the nuclear weapon on the international system -indeed, not much impression that there is an international system. This is perhaps the most conventional of all of the books and shows least sign of having been affected by the explosive thought of the past ten years.

The Haas and Whiting book I found mostly depressing, as its general theme seems to be that nothing can really be done about anything, man is hopelessly trapped in his present institutions, integrative movements are impossible and international organization a chimera. After reading Chapter 16, a case study of Nazi Germany which does not even mention the role of the Jews, I must conscientiously report that I was too depressed to read the rest of the book.

So much for a general impression of the texts. The reader has some right to know what is the content of these books, what subjects they treat and what topics they stress, for this is a clue to the content of the discipline of international studies. Not having the funds for a content analysis of the texts themselves, I contented myself with a rough analysis of the six indexes. The results are, of course, a function of the adequacy of the indexes themselves; however, with one possible exception, the books had full (and about equally full) indexes. ${ }^{1}$ The results are of some interest. Out of a total of nearly 2,500 index entries in the combined index, only 46 were common to all six books, another 60 were in five of the books, and another 85 in four of them; thus only 191 entries were in more than three of the books. I would take this to be a measure of the scattered nature of the field and the small dimensions of the common core

\footnotetext{
${ }^{1}$ I must thank Russell Boulding for assist-
} ance in abstracting the indexes. of material. The following are the items with the largest number of individual entries, which gives some idea of the preoccupations of the authors: United States (657), Soviet Union and Russia (533), United Nations (369), France (280), Great Britain (263), China (235), Diplomacy and Diplomats (179), Balance of Power (161), India (161), Power (157), Japan (156), Communism (137), World War II (137), Nationalism (131), League of Nations (129), NATO (116), Italy (112), Hitler (96), Foreign Policy (96), Colonialism and Colonies (91), International Organization (90), Korea (89), Collective Security (86), Ideology (86), Sovereignty (81), Disarmament (72), Egypt (68), Africa (67), Indonesia (60), Poland (58), Canada (57), Churchill, Winston (57), Morality (57), Military and Militarism (53), Regionalism (53), Czechoslovakia (53), Atom Bomb (50), Pakistan (50), Belgium (50), Israel (50), Propaganda (48), Yugoslavia (45), Khrushchev (43), World War I (43), Hungary (41), Democracy (40), Turkey (40), American Organizations (39), Peace (38), Population (37), European Coal and Steel Community (36), Woodrow Wilson (35).

It seems clear that, at least as measured by index entries, the main preoccupation of international studies is with nations themselves as entities ( 20 items out of the first 50 ), with abstract ideas second (about 13), and institutions third (about 8). This may be due partly to a bias in indexing-it is relatively easy to index the name of a country-but the results are at least suggestive. Peace and Population do not score very high, but neither does Military and Militarism. Persons score surprisingly low. The "perspective" of American authors is clearly revealed, both as to time and place; we are heavily oriented towards Europe and Asia, very little to South America and Africa. 
At the other end of the scale the "low scorers" are also significant as a measure of what is not salient in the minds of the writers of these texts. There are too many, of course, to list and the reader will have to rely on my subjective judgment. The following items, however, surprised me. Among those having only one reference in all six books were: Aliens, Angell (Robert C.), Appeasement, Arms Race, Auschwitz, Authoritarianism, Bacteriological Warfare, Birth Control, Boundaries, Briand-Kellogg Pact, Buchenwald, Bureaucracy, Capability, Christianity, Community (French), Concentration Camps, Conflict, Connally Amendment, Death Rates, Decision-Making, Dialectic, Disengagement, Dumping, Dynastic State, Economic Development, Education, Emigration, Equilibrium, Ethics, Extradition, Feudalism, Four Freedoms, Freud, Goa, Gold Standard, Great Leap Forward, GNP, Hegel, Hinduism, History, H-bomb, IBRD, Idealism, Immigration, Integration, IDA, Isolationism, Keynes, Kulaks, Legislation, Legitimacy, Locke, Massive Retaliation, Mercantilism, Nuclear War, Pacifism, Passive Resistance, Parliamentary Government, Patriotic Groups, Polaris Missiles, Pragmatism, Radioactivity, Rapoport (A.), Research, Rights of Man, Schelling (T.), Social Science, Strontium 90, Submarine, Tank, U-2, Union Now, United World Federalists, Universal Declaration of Human Rights, UMT, Violence.

Some total absences of reference were also a little surprising. It is hard, of course, to think of what is not in an index, but without too much thought I listed the following absences: Lewis F. Richardson, Selective Service, Conscription, I. F. Stone, Guantánamo Bay, Sadism, and Masochism.

It seems clear from this analysis, inadequate as it is, that international studies is reaching the student through a pretty sizable filter. In the first place there is a con- vention about what subjects are important. Nations are just fine to talk about-which is not of course unreasonable, as the subject of international studies is presumably the relations of nations. Some abstract ideas are fine, especially those remote from human beings and related to abstract political notions or entities, such as nationalism, sovereignty, etc. There are, however, censors. Some of these relate to the more unpleasant aspects of the national state. International studies after all studies nations, and we don't want to say things that are too unpleasant about the objects of our study. Bacteriologists presumably develop a certain fondness for germs. So International Studies People (there may be a name for the discipline, but there is as yet no name for the people who practice it) develop a fondness for nations, and soft-pedal such things as concentration camps, anti-Semitism, bacteriological warfare, nuclear fallout, or immigration restrictions. Oddly enough, this censor operates to play down an essential element in the international system, which is the organization and operation of an armed force. Insofar as the international system is a threat system, one would think that the armed forces were an essential part of it; in all these books, however, there is no adequate discussion of military theory, and practically nothing of the whole new body of theory developed by the nuclear weapon. The Padelford and Lincoln book naturally comes closest to this, with Professor Lincoln at West Point, but even here there is little sense that military theory is an essential part of international relations. One detects a secret shame about the classical concept of war as an extension of diplomacy, or its corollary, diplomacy as a prelude to war. The student who gets his knowledge of international relations from these books receives an image of shadowy entities known as nations interacting something like per- 
sons in spite of some disclaimers, but he will not get any appreciation of the role of the armed forces, usually the largest single organization within any nation, as an essential and partly autonomous element in this system.

The censor operates doubly when it comes to the shadier aspects of the military system itself, and even accounts perhaps for the fact that there is only a single reference to Freud. Imagine six textbooks in international relations without a single reference to Selective Service, Conscription, Sadism, and Masochism! Perhaps the student is just supposed to know about these things, or is it assumed that the armed forces are entirely manned by lab technicians recruited on a volunteer basis?

The censor operates also along the toughtender continuum to eliminate those aspects of the international system which lie towards the tender end of the scale. Interest and Power are fine topics for discourse; Love, Sympathy, Consent, Self-sacrifice, and Idealism are not. Consequently, if we except some insightful passages in Morgenthau, there is practically nothing in these works which will point the student towards an understanding of those slow, subtle, but immensely powerful tides in the history of man's images and values by which the circle of concern and affection has widened to include family, tribe, clan, nation, and is in process of widening to include the world.

It is one of the peculiar trials of the textbook writer that his work becomes obsolete even before type is set. In a field which is developing as rapidly as international studies, this hazard is particularly great, and I would class all of these six texts as substantially obsolete even before some of them were written. The writer in this field has an additional hazard, that the international system itself changes with great rapid- ity, so that even his descriptive material soon becomes ancient history, and his predictions have a depressing habit of being falsified almost as soon as he makes them One attempt to deal with this situation is the Reader, which republishes quickly the articles and other short pieces which constitute, as it were, the sallies and forays of the advancing science. Rosenau's collection is an excellent example of such a Reader, and brings together a comprehensive selection of articles and essays covering most aspects of the advancing field. I know of no theory of the anthology that says what should go in and what should be left out, and I find Rosenau's selection very satisfying, in the sense at least that I cannot think of anything else I want to put in; indeed, one might well object that too much has gone in and that a smaller, handier volume would have been better. However, here is an excellent broad sample of recent writing.

The contrast with the textbooks is striking. Unfortunately the book has no index, so it has not been possible to compare its content with the six texts, but it is oriented heavily towards theoretical systems and towards a broad, integrated social science approach. What is lacking is perhaps the vital link between the empirical and historical material and the theoretical systems which are burgeoning. This is a late stage in the development of a discipline, and it is still early to expect genuine system-testing against empirical material. It is interesting to note that of the eight authors of the six texts, only three-Haas, Morgenthau, and Organski-are represented in this collection; the frontiersmen and the text-cultivators are not, for the most part, of the same circle.

The last work (McClelland's report) stands apart from the others as a report on a project which involved research into the teaching of international relations, with an attempt to get at some of the deeper images 
of students by means of moderate-depth interviews, and an attempt to assess the effectiveness of an experimental teaching program at San Francisco State College. The author is chary of drawing conclusions, but the findings reinforce evidence from a number of different sources that formal college instruction, however well done, does little to change basic values and attitudes, which often lie deep within the personality and form a component of the image which is highly resistant to change even in the face of unfavorable messages. The results of the moderate-depth interviews were interesting in revealing, first, a deep-hidden fear of "brainwashing" which probably reflects a point of conflict between the "folk" culture of the home and the "secular" culture of the college; and, secondly, a deep uneasiness about being "overrun" by hordes of aliens which leads to a suspicious, defensive, and nonintegrative attitude. It is also interesting how many attitudes-even virtuous ones -which seem fairly fundamental are based on highly inaccurate factual information. It would have been interesting to pursue further the sources of much of this misinformation.

Studies of this kind serve to temper any optimism one might have about the efficacy even of the best college textbooks. It is one of the pains, but occasionally also one of the comforts, of college teaching that by the time the student comes to college it is usually too late to do him much good or harm by formal teaching. Perhaps the most important aspect of college teaching is not so much the impact which it makes on the student as the impact which it makes on the teacher. It is largely in college teaching that the sophisticated images of society are created. It is in this small subculture of people who teach and write about interna- tional systems, for instance, that a new image of the international system, capable of much more accurate testing for reality, is being worked out. The new image, it is hoped, will eventually penetrate the folk images which most people cherish and by which so many crucial decisions are guided. The textbook writers are at least beginning to show this change; if the Rosenau book of readings is evidence of things to come, there will be a radical change in the textbooks themselves within the next few years. Slowly these more accurate images will seep into the folk culture and eventually-perhaps, in these days of rapid change, fairly soon-will begin to guide the decisions of the powerful. By these slow means the very nature of the international system is changed, for it is largely what men think it is, and we may have a reasonable hope that the result of all this mental effort will be a change for the better.

\section{REFERENCES}

HaAs, Ehnst B. and Allen S. Whrting. Dynamics of International Relations. New York: McGraw-Hill, 1956.

McCleldand, Chardes A. "College Teaching of International Relations." San Francisco, Calif.: San Francisco State College, 1962. (Multilithed.)

Morgenthau, Hans J. Politics Among Nations. 3rd ed. New York: Alfred A. Knopf, 1960.

Organski, A. F. K. World Politics. New York: Alfred A. Knopf, 1958.

Padelford, Norman J., and George A. LiNCOLN. The Dynamics of International Politics. New York: Macmillan, 1962.

Rosenau, James N. (ed.). International Politics and Foreign Policy: A Reader in Research and Theory. New York: The Free Press of Glencoe, 1961.

Schleicher, Charles P. International Relations. Englewood Cliffs, N.J.: Prentice-Hall, 1962.

Storssinger, Jown G. The Might of Nations. New York: Random House, 1961. 